\title{
Purification and Characterization of Two Phage PBSX-induced Lytic Enzymes of Bacillus subtilis 168: An $N$-Acetylmuramoyl-L-alanine Amidase and an $\boldsymbol{N}$-Acetylmuramidase
}

\author{
By J. BARRIE WARD, *† CAROL A. M. CURTIS, CHRISTOPHER \\ TAYLOR AND ROGER S. BUXTON \\ Division of Microbiology, National Institute for Medical Research, Mill Hill, \\ London NW7 1AA, U.K.
}

(Received 24 September 1981; revised 8 December 1981)

\begin{abstract}
After heat-induction of the defective phage PBSX in a xhi-1479 mutant of Bacillus subtilis 168 , the culture lysed rapidly even if the lyt-2 mutation was present (which greatly reduces the amount of the bacterial autolysins). Two lytic enzymes, an $\mathrm{N}$-acetylmuramoyl-L-alanine amidase and an endo- $N$-acetylmuramidase, were purified from the culture supernatant. The amidase was readily distinguished from the bacterial amidase by its low molecular weight. In addition, it was not inhibited by antibody directed against the bacterial enzyme. These results indicate that PBSX does not rely on the bacterial autolysins to accomplish lysis.
\end{abstract}

\section{IN TR ODUCTION}

When the defective bacteriophage PBSX carried by Bacillus subtilis 168 is induced from the prophage state, a lytic agent is produced. This results in lysis of the host bacteria and release of the progeny phage particles. Since PBSX is defective, not being capable of infectious growth, it was possible that the bacteriophage has lost the ability to produce its own lytic enzyme and makes use of the bacterial autolysins. In $B$. subtilis, these have been characterized as an $N$-acetylmuramoyl-L-alanine amidase and an endo- $\beta$ - $N$ acetylglucosaminidase (Rogers, 1979; Herbold \& Glaser, 1975; Taylor et al., 1980). Alternatively, the bacterial autolysins may in fact be phage-coded. This situation would explain why PBSX and other related defective phages have been retained by $B$. subtilis during evolution.

In this paper we have attempted to examine this problem by characterizing the lytic enzyme produced upon induction of PBSX. The phage was induced in B. subtilis 168 carrying the xhi-1479 mutation which is located in the prophage. This mutation results in the specific induction of PBSX when the growth temperature of the host organism is raised to $48^{\circ} \mathrm{C}$ (Buxton, 1976). In this respect, the xhi-1479 mutation is formally analogous to the cI857 mutation of bacteriophage $\lambda$ (Sussman \& Jacob, 1962) and probably resides in the gene specifying the phage repressor. In order to minimize any possible contamination by the two $B$. subtilis autolysins, a strain carrying the lyt-2 mutation was used. This mutation results in a $90-95 \%$ deficiency of both the autolytic enzymes (Fein \& Rogers, 1976); thus, most of the lytic activity present in heat-treated cultures should be present as a consequence of the induction of PBSX. Moreover, the fact that this xhi lyt mutant undergoes heat-induced lysis (Buxton, 1980) makes it unlikely that lysis due to PBSX induction is mediated by the two bacterial autolysins.

† Present address: Department of Microbial Biochemistry, Glaxo Group Research Ltd, Greenford, Middx UB6 OHE, U.K. 


\section{METHODS}

Organisms and cultural conditions. All the experiments on the isolation and characterization of the PBSX-induced lytic enzyme were performed with Bacillus subtilis strain RB1163 (xhi-1479 lyt-2). This was constructed using saturating concentrations of DNA isolated from strain RB 1050 (pyrX xhi-1479) to transform strain FJ6 (metC3 lyt-2) (Fein \& Rogers, 1976) to $\mathrm{Met}^{+}$and screening these recombinants for inheritance of $x$ hi- 1479 by testing for the absence of growth at $48^{\circ} \mathrm{C}$. Bacillus subtilis strain RB1163 is, therefore, heat-sensitive ( $x h i)$ and forms chains of unseparated bacilli $(l y t)$.

Other organisms used were B. subtilis 168, B. subtilis W23, Bacillus licheniformis strains 94 and 6346, Micrococcus luteus NCTC 2665 and Staphylococcus aureus H.

Cultures for the induction of the PBSX lytic enzyme were grown at $35^{\circ} \mathrm{C}$ in casein hydrolysate/yeast extract (CHY) medium. Otherwise, cultures were grown in tryptone/yeast extract (TYE) medium or casein hydrolysate/salts (CHSC) medium supplemented as required to meet auxotrophic requirements (Ward, 1974; Tynecka \& Ward, 1975).

Measurements of lytic activity. In most cases lysis of walls was measured turbidimetrically by resuspending the walls in $25 \mathrm{~mm}$-Tris/ $\mathrm{HCl}$ buffer, $\mathrm{pH} 7 \cdot 1$, containing $10 \mathrm{mM}-\mathrm{MgCl}_{2}$ at $37^{\circ} \mathrm{C}$ and following the decrease in absorbance at $380 \mathrm{~nm}$. One unit of lytic activity gave a decrease in absorbance of $0.001 \mathrm{~min}^{-1}$ during the initial period of linear decrease. Alternatively, radioactive walls were resuspended in the above buffer and lysis was allowed to occur at $37^{\circ} \mathrm{C}$ for periods of $10-30 \mathrm{~min}$. After centrifuging (15000 $\mathrm{g}$ for $5 \mathrm{~min}$ ), the amount of soluble radioactivity in the supernatant was determined.

Preparation of walls and wall fractions. Walls treated with hot detergent (sodium dodecyl sulphate, SDS) to inactivate autolytic enzymes and extract associated proteins were prepared from B. subtilis $168, B$. subtilis W23, $B$. licheniformis 6346, M. luteus NCTC 2665 and $S$. aureus H as described by Fein \& Rogers (1976). Radioactive walls were prepared by the same method from $B$. subtilis 168 grown in CHSC medium containing $N$ - $\left[{ }^{14} \mathrm{C}\right.$ lacetylglucosamine: the purified walls were labelled with $1.63 \times 10^{5}$ d.p.m. ${ }^{14} \mathrm{C} \mathrm{mg} \mathrm{mg}^{-1}$. Soluble uncross-linked peptidoglycan was isolated from cultures of $B$. licheniformis 94 treated with benzylpenicillin (Tynecka \& Ward, 1975). Disaccharide monomer ( $N$-acetylglucosaminyl- $N$-acetylmuramoyl-L-alanyl-Disoglutamyl-meso-diaminopimelic acid) and bis-disaccharide dimer were prepared from walls of $B$. subtilis 168 or B. licheniformis 94 after treatment with egg-white lysozyme (EC 3.2.1.17) (Ward, 1974). Purified peptidoglycan was isolated from the same walls after treatment with either $5 \%(\mathrm{w} / \mathrm{v})$ trichloroacetic acid at $2{ }^{\circ} \mathrm{C}$ for $48 \mathrm{~h}$ or with $60 \%(\mathrm{w} / \mathrm{v})$ hydrofluoric acid at $-10^{\circ} \mathrm{C}$ for $24 \mathrm{~h}$ to remove teichoic and teichuronic acids.

Antiserum to bacterial amidase. The bacterial $N$-acetylmuramoyl-L-alanine amidase was purified from $B$. subtilis 168 by the method of Herbold \& Glaser (1975) and antisera to this purified protein were raised in rabbits. Antibody to the amidase was purified by ion-exchange chromatography on DEAE-cellulose and isoelectric focusing. Details of this purification procedure and the specificity of the isolated antibody will be described elsewhere.

Analytical methods. The release of free amino groups produced during lysis was assayed as described by Forsberg \& Ward (1972). Dinitrophenylated (DNP) fragments of walls were hydrolysed in $4 \mathrm{M}-\mathrm{HCl}$ at $100{ }^{\circ} \mathrm{C}$ for either $4 \mathrm{~h}$ or $16 \mathrm{~h}$. DNP-alanine was separated from the hydrolysate by thin-layer chromatography on silica gel plates (Merck silica gel 60) using chloroform/methanol/acetic acid $(95: 5: 1$, by vol.) as the solvent. The spots were eluted with methanol/1 $\mathrm{M}-\mathrm{NH}_{4} \mathrm{OH}(1: 1, \mathrm{v} / \mathrm{v})$ and the absorbance of the eluate was read at $360 \mathrm{~nm}$; the molar absorption coefficient of DNP-alanine was taken as $150001 \mathrm{~mol}^{-1} \mathrm{~cm}^{-1}$ (Ghuysen et al., 1966). To establish the configuration of the alanine released, the circular dichroism spectrum of the DNP-derivative (purified as described above and dissolved in $0.125 \mathrm{M}-\mathrm{NaHCO}_{3}$ ) was compared with the circular dichroism spectra of DNP-alanine of known configuration using a Jasco J41C Spectropolarimeter. These measurements were performed by $\mathrm{Dr} S$. R. Martin of this Institute.

The release of free reducing groups was assayed by the Thompson \& Shockman (1968) modification of the method of Park \& Johnson using $N$-acetylglucosamine as the standard. The reducing groups were further characterized after reduction with $\mathrm{KB}^{3} \mathrm{H}_{4}$ and acid hydrolysis as described by Williamson \& Ward (1979).

Protein was measured by the Lowry method using bovine serum albumin as standard. Radioactivity in walls or solubilized peptidoglycan was determined using a toluene-Biosolv scintillation fluid as described previously (Wyke \& Ward, 1977).

\section{RESULTS}

\section{Purification of the PBSX-induced lytic enzymes}

Bacillus subtilis RB1163 was grown in broth at $35^{\circ} \mathrm{C}$ until the culture reached an $A_{600}$ of approximately 0.5 . It was then transferred to $48{ }^{\circ} \mathrm{C}$ where growth continued for a short period to reach an $A_{600}$ of $1.2-1.5$ before lysis began. After $60-75$ min incubation at the 


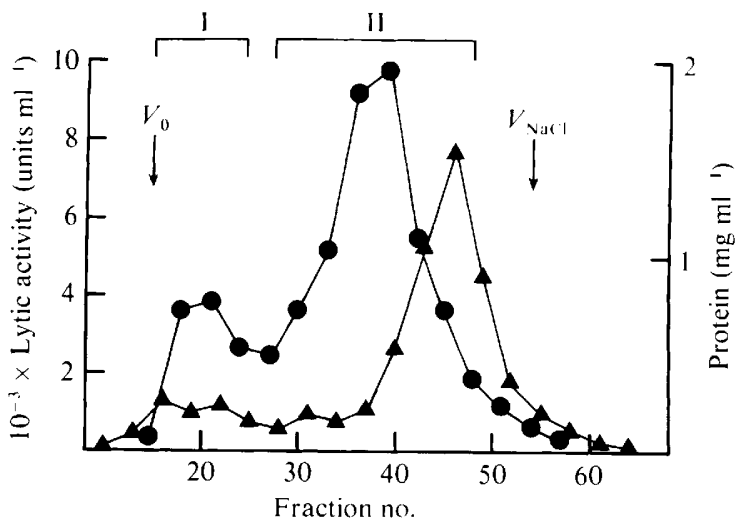

Fig. 1. Separation by chromatography on Sephadex G-100 of the two PBSX-induced lytic enzymes of $B$. subtilis 168. Samples were assayed for lytic activity $(\mathbf{O})$ and protein $(\mathbf{\Delta})$. Fractions were pooled for enzyme I and enzyme II as shown. The void volume $\left(V_{0}\right)$ and $\mathrm{NaCl}$ elution volume $\left(V_{\mathrm{NaCl}}\right)$ of the column are indicated by the arrows.

higher temperature, lysis was complete $\left(A_{600} 0 \cdot 02\right)$. Cell debris was removed by centrifuging the culture $\left(16000 \mathrm{~g}, 4^{\circ} \mathrm{C}\right.$ for $\left.10 \mathrm{~min}\right)$ and the supernatant was used for subsequent enzyme purification.

Initial experiments showed that the lytic enzyme could be absorbed from supernatants on to $B$. subtilis walls. However, all attempts to release the bound enzyme by treatment of the walls with high concentrations of $\mathrm{LiCl}$ or $\mathrm{NaCl}$ were unsuccessful. As a result the following purification procedure was developed.

The culture supernatant was passed successively through columns $(20 \times 1.5 \mathrm{~cm})$ of DEAE-cellulose equilibrated with $50 \mathrm{~mm}$-Tris/ $\mathrm{HCl}, \mathrm{pH} 7 \cdot 1$, and Amberlite $\mathrm{CG}-50\left(\mathrm{H}^{+}\right)$. The lytic activity was not absorbed by the DEAE-cellulose and was bound to the Amberlite. This column was washed with water until the $A_{280}$ of the eluate had decreased to almost zero. Lytic activity was not detected in either the initial column eluate or in the water washes. The column was then eluted with $2 \mathrm{M}$-ammonium acetate and fractions $(4 \mathrm{ml})$ were collected. Those containing the lytic activity were pooled. At this stage of the purification the yield of lytic activity appeared to drop substantially but this was probably due to the high concentration of salt present in the assay. The pooled fractions were concentrated by filtration through an Amicon ultrafilter using a UM-10 membrane. Attempts to concentrate the lytic activity by precipitation with $\left(\mathrm{NH}_{4}\right)_{2} \mathrm{SO}_{4}$ followed by dialysis to remove salt were not successful and resulted in considerable loss of activity. The non-diffusible fraction obtained by ultrafiltration contained all the lytic activity present in the pooled material and was chromatographed on a column $(68 \times 1.5 \mathrm{~cm})$ of Sephadex G-100 eluted with $10 \mathrm{~mm}$-morpholinopropanesulphonic

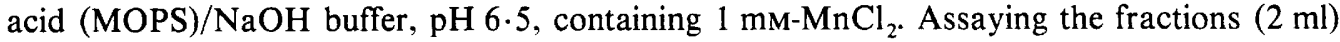
revealed the presence of two peaks of lytic activity (Fig. 1). The minor fraction (enzyme I) was of high molecular weight and was eluted close to the void volume of the column, whereas the major peak of lytic activity (enzyme II) was eluted just ahead of the salt. Again, appropriate fractions were pooled and the enzymes were concentrated by ultrafiltration. An interaction of several lytic enzymes with Sephadex results in anomalous behaviour by such enzymes (Williamson \& Ward, 1981). A similar interaction might have been responsible for the elution profile of enzyme II; consequently, the concentrated enzyme II activity was re-chromatographed on a column $(65 \times 1.5 \mathrm{~cm})$ of Biogel P-100 eluted with $0.1 \mathrm{M}^{-}$ MOPS/ $\mathrm{NaOH}$ buffer, $\mathrm{pH} 6 \cdot 5$, containing $1 \mathrm{mM}-\mathrm{MnCl}_{2}$. The enzyme was again eluted as a single peak of low molecular weight but in this case clearly ahead of the salt. Samples of the pooled enzymes were examined by SDS-polyacrylamide gel electrophoresis. Enzyme I was separated into several major and minor bands of protein, whereas enzyme II gave two bands 
Table 1. Purification of PBSX-induced lytic enzymes

\begin{tabular}{|c|c|c|c|c|c|c|c|c|}
\hline \multirow[b]{2}{*}{ Fraction } & & \multicolumn{2}{|c|}{ Lytic activity } & \multicolumn{2}{|c|}{ Protein } & \multirow{2}{*}{$\begin{array}{c}\text { Specific } \\
\text { activity } \\
\text { |units (mg } \\
\text { protein })^{-1} \mid\end{array}$} & \multirow[b]{2}{*}{$\begin{array}{c}\text { Recovery } \\
(\%)\end{array}$} & \multirow[b]{2}{*}{$\begin{array}{l}\text { Purification } \\
\text { factor }\end{array}$} \\
\hline & $\begin{array}{l}\text { Volume } \\
\quad(\mathrm{ml})\end{array}$ & units $\mathrm{ml}^{-1}$ & $\begin{array}{l}\text { Total } \\
\text { units }\end{array}$ & $\mathrm{mg} \mathrm{ml}^{-1}$ & $\begin{array}{c}\text { Total } \\
\mathrm{mg}\end{array}$ & & & \\
\hline Culture supernatant & 1800 & $79 \cdot 1$ & 142000 & $2 \cdot 30$ & 4140 & $34 \cdot 4$ & 100 & 1 \\
\hline DEAE-cellulose eluate & 1800 & $78 \cdot 3$ & 141000 & 1.00 & 1800 & $78 \cdot 3$ & $99 \cdot 2$ & $2 \cdot 28$ \\
\hline $\begin{array}{l}\text { Amberlite CG- } 50 \text { eluate } \\
\text { (Amicon concentrated) }\end{array}$ & $3 \cdot 7$ & 5330 & 19000 & $9 \cdot 13$ & 33.8 & 583 & $13 \cdot 4$ & $16 \cdot 9$ \\
\hline \multicolumn{9}{|l|}{$\begin{array}{l}\text { Sephadex G-100 eluate } \\
\text { (Amicon concentrated) }\end{array}$} \\
\hline Enzyme I & 1.8 & 3800 & 6800 & 0.71 & $1 \cdot 28$ & 5352 & $4 \cdot 8$ & 156 \\
\hline Enzyme II & $3 \cdot 3$ & 20150 & 66500 & 0.68 & $2 \cdot 24$ & 29688 & $46 \cdot 8$ & 863 \\
\hline
\end{tabular}

of protein, one of apparent molecular weight 30000 and a smaller amount of molecular weight 14500.

The results of a typical purification of the two enzymes are shown in Table 1 . The final products had specific activities of $5.35 \times 10^{3}$ and $2.97 \times 10^{4}$ units (mg protein) $)^{-1}$ for enzymes I and II, respectively, and represented approximately $50 \%$ of the lytic activity originally present.

\section{Characterization and properties of the purified enzymes}

\section{Enzyme I}

When assayed in $0.01 \mathrm{M}-\mathrm{MOPS} / \mathrm{NaOH}$ buffer $(\mathrm{pH} 5 \cdot 6-8 \cdot 2)$ the lytic activity had a broad $\mathrm{pH}$ optimum over the range 7.0-8.0. Activity in $0.01 \mathrm{M}$-acetate buffer $(\mathrm{pH} \mathrm{4.5-5.8)}$ and $0.01 \mathrm{M}$-glycine $/ \mathrm{NaOH}$ buffer ( $\mathrm{pH} 8 \cdot 0-9.4$ ) was considerably lower. These assays did not take into account changes in ionic strength of the various buffers. Lytic activity was also influenced by ionic strength and when assayed in MOPS/ $\mathrm{NaOH}$ buffer, $\mathrm{pH} 7 \cdot 1$, the enzyme showed maximum activity in the concentration range of $0.005-0.015 \mathrm{M}$ buffer.

Lysis of B. subtilis walls was accompanied by an increase in the reducing power of the suspension but with little concomitant increase in the number of free amino groups present (Fig. $2 a$ ). Thus, lysis appeared to result from the action of a glycosidase and not from $\mathrm{N}$-acetylmuramoyl-L-alanine amidase or endopeptidase activities. To determine the specificity of the glycosidase, samples of walls, and of the soluble products obtained after lysis was allowed to proceed for $6 \mathrm{~h}$, were reduced with $\mathrm{KB}^{3} \mathrm{H}_{4}$ to radioactively label the free reducing groups present. The reduced samples were then hydrolysed, and after chromatography of the hydrolysate on Dowex-50, the proportions of the various hexosamines and $\left[{ }^{3} \mathrm{H}\right]$ hexosaminols were determined (Table 2). The walls contained galactosamine from the glucosyl- $N$ acetylgalactosamine phosphate polymer (Shibaev et al., 1973) in addition to glucosamine and muramic acid from peptidoglycan. Glucosamine and galactosamine were not separated by the Dowex-50 column. After reduction of the walls, radioactivity was found chiefly as $\left[{ }^{3} \mathrm{H}\right]$ glucosaminol, and the average length of the glycan chains in the peptidoglycan was $46 \cdot 7$ disaccharides. This value was calculated from the ratio of free reducing groups present in muramic acid and glucosamine to the total amount of muramic acid present. Reduction of $B$. subtilis walls or the soluble products obtained after treatment with Myxobacter AL-1 amidase or lysozyme does not give free reducing groups of galactosamine (S. M. Fox \& J. B. Ward, unpublished observations). After lysis with enzyme I for $6 \mathrm{~h}$ the total free reducing groups of muramic acid had increased approximately 30 -fold whereas no significant change was found for glucosamine. At this time the average chain length of the glycan was reduced to $7 \cdot 1$ disaccharides. Thus, enzyme $\mathrm{I}$ is an endo- $N$-acetylmuramidase and the increase in free amino 


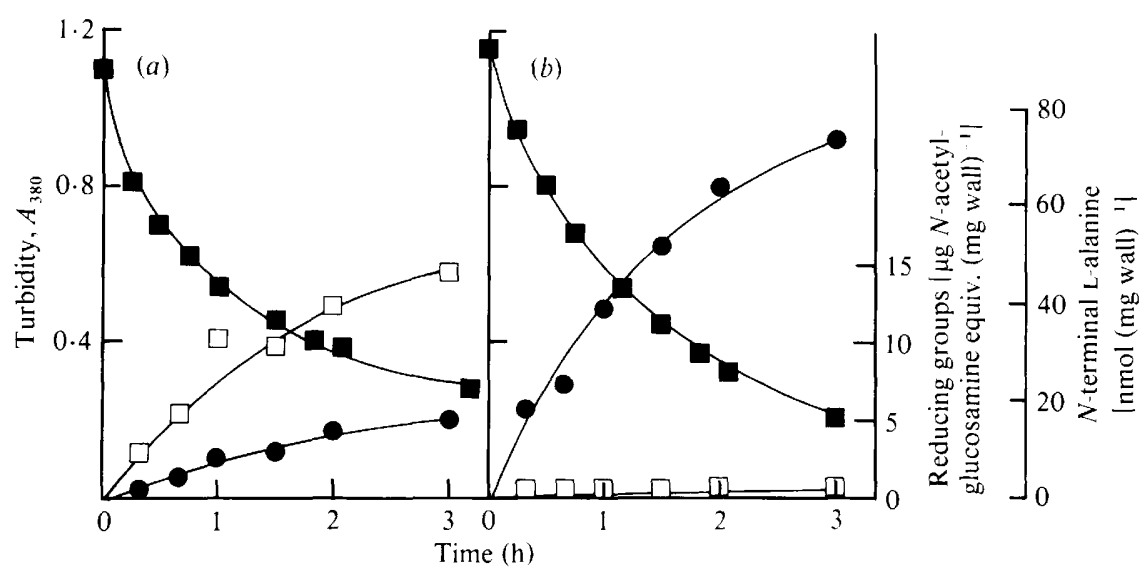

Fig. 2. Lysis of B. subtilis walls by the purified enzymes produced after heat-induction of phage PBSX. Walls $\left(1 \mathrm{mg} \mathrm{m}^{-1}\right)$ were resuspended in $0.01 \mathrm{M}-\mathrm{MOPS} / \mathrm{NaOH}$ buffer, $\mathrm{pH} 7.1$, at $37^{\circ} \mathrm{C}$ and the decrease in turbidity was followed at $380 \mathrm{~nm}(\boldsymbol{\square})$. Samples were assayed at intervals for reducing power (D) and $N$-terminal amino groups (O). (a) Enzyme I, the $N$-acetylmuramidase. (b) Enzyme II, the $N$-acetylmuramoyl-L-alanine amidase.

Table 2. Analysis of hexosamines obtained from reduced B. subtilis walls and after treatment with enzyme I

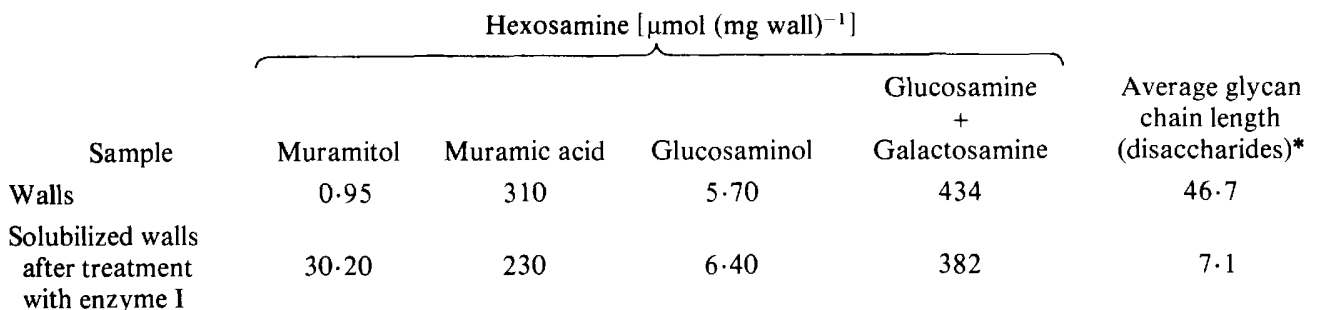

* Calculated from the ratio of free reducing groups (as muramitol and glucosaminol) to the total amount of muramic acid present (muramic acid plus muramitol).

groups observed during lysis of the walls presumably arises from the activity of contaminating enzyme II (see below).

\section{Enzyme II}

Using identical assays to those described above for enzyme I, enzyme II had a $\mathrm{pH}$ optimum of 7.5 and maximum activity in $0.005-0.01 \mathrm{M}-\mathrm{MOPS} / \mathrm{NaOH}$ buffer, $\mathrm{pH} 7.5$. Lytic activity was also influenced by divalent cations present in the assay mixture. Any metal ions present in the enzyme preparation could be removed by chromatography on Sephadex G-25 (eluted with

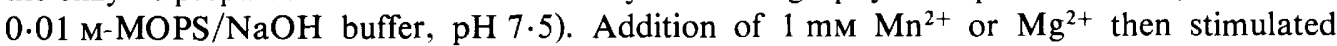
activity 2 - and 1.7 -fold, respectively, while $\mathrm{Ca}^{2+}$ and $\mathrm{Zn}^{2+}$ were without effect. Lytic activity was completely inhibited by $\mathrm{Hg}^{2+}$ and $\mathrm{Fe}^{3+}$, whereas addition of $1 \mathrm{~mm}$-EDTA resulted in $25-50 \%$ inhibition. The purified enzyme was relatively stable and only a small loss of activity was observed on storage at $2{ }^{\circ} \mathrm{C}$ for several weeks. The molecular weight of enzyme II was determined by comparison of the elution volumes on Biogel P-100 (eluted with $0.1 \mathrm{M}$ MOPS/ $\mathrm{NaOH}, \mathrm{pH} 7 \cdot 0$, containing $1 \mathrm{mM}-\mathrm{MnCl}_{2}$ ) of cytochrome $c$ (mol. wt 12380), trypsin inhibitor (mol. wt 21000), pepsin (mol. wt 34700), egg albumin (mol. wt 45000) and bovine serum albumin (mol. wt 66000) with that of the enzyme. An apparent molecular weight of 14800 was obtained. 
Lysis of $B$. subtilis walls by enzyme II resulted in a large increase in the number of free amino groups present but no increase in free reducing groups (Fig. $2 b$ ). Dinitrophenylation and hydrolysis of the soluble products obtained after lysis for $6 \mathrm{~h}$ showed the free amino groups to be present as alanine. Further examination of the DNP-alanine by circular dichroism established it to be the L-isomer. Thus, enzyme II is an $\mathrm{N}$-acetylmuramoyl-L-alanine amidase. It could be readily distinguished from the major autolysin of $B$. subtilis, which also is an $\mathrm{N}$-acetylmuramoyl-L-alanine amidase, by molecular weight, that of the bacterial enzyme being 51000 (Herbold \& Glaser, 1975). Moreover, enzyme II was not inhibited by purified antibody which was raised against, and inactivated, the bacterial amidase (Taylor et al., 1980).

\section{Specificity of the enzymes}

The purified enzyme II lysed walls of $B$. subtilis W23 and B. licheniformis strains 94 and 6346. In each case the activity of the preparation was similar to that observed with the walls of $B$. subtilis 168 . In each of these organisms the basic structure of the peptidoglycan is the same although the nature of the secondary polymers present (the teichoic and teichuronic acids) show considerable differences.

The amidase had no demonstrable activity on the walls of $M$. luteus and $S$. aureus $\mathrm{H}$, or on uncross-linked peptidoglycan, disaccharide monomer and bis-disaccharide dimer prepared from $B$. licheniformis 94 and $B$. subtilis 168. Enzyme I showed some slight activity against walls of $M$. luteus in MOPS/ $\mathrm{NaOH}$ buffer, $\mathrm{pH} 7 \cdot 1$, whereas in sodium acetate buffer, $\mathrm{pH} 4.5$, no activity could be detected. Walls of $M$. luteus have been used previously at $\mathrm{pH} 4.5-5.0$ as a specific substrate for the endo- $\beta$ - $N$-acetylglucosaminidase, the second autolysin of $B$. subtilis (Fan \& Beckman, 1973; Taylor et al., 1980).

On the basis of the above experiments the PBSX-induced amidase shows a requirement for cross-linked peptidoglycan of the type found in the walls of bacilli. The nature of the secondary polymers present in these walls appears to have only a marginal effect on lytic activity.

\section{DIS CUS SION}

The results presented in this paper demonstrate that two previously unidentified autolytic enzymes, an endo- $N$-acetylmuramidase and an $N$-acetylmuramoyl-L-alanine amidase, are synthesized by $B$. subtilis 168 when the defective phage PBSX is induced by heating a xhi-1479 mutant. The muramidase activity was not detected in uninduced bacteria although small amounts of bacterial amidase were found (Fein \& Rogers, 1976). It therefore seems reasonable to conclude that the enzymes described in the present study are associated with the induction of this particular phage. This conclusion is strengthened by the fact that the xhi-1479 mutation, which maps in the PBSX prophage, is specific for the induction of PBSX. A second phage, $\phi 105$, is not induced (Buxton, 1976). The use of a strain carrying the lyt-2 mutation minimized contamination by the two known bacterial autolysins. In fact, the results demonstrate that the two new autolytic enzymes are easily distinguishable from the bacterial enzymes. Thus, one is an endo- $N$-acetylmuramidase, a type of enzyme unknown in $B$. subtilis 168 although found in another strain of $B$. subtilis (Takahara et al., 1974). The other, an $\mathrm{N}$-acetylmuramoyl-L-alanine amidase, had an apparent molecular weight of 14800 , whereas that of the bacterial amidase is 51000 . Moreover, the new amidase was not inhibited by purified antibody raised against the bacterial amidase and, unlike the bacterial amidase (Herbold \& Glaser, 1975), the nature of the secondary polymers present in the wall had little effect on lytic activity. These results eliminate the possibility that PBSX uses the known bacterial autolysins to accomplish phage-induced lysis of the bacterium. We cannot, however, be certain that the two new autolysins are phage-coded. By comparison with other bacteriophages, this conclusion seems likely, but since PBSX is defective, it still remains a 
possibility that the genes specifying these enzymes lie elsewhere than in the prophage. In this case, their synthesis must be controlled by the phage. Only by the isolation and mapping of mutants affecting the autolysins, the equivalent of $\mathrm{R}$ mutants in phage $\lambda$ (Campbell \& Del Campillo-Campbell, 1963), can this question be answered. To date, information regarding the position of the structural genes coding for the bacterial enzymes has not been published $(\mathrm{H}$. J. Rogers, personal communication).

As far as we are aware, there are no previous reports of two distinct autolysins being associated with phage induction. The significance of this observation remains unclear; one possibility is that the bacterial and phage-induced enzymes may have arisen by gene duplication. Perhaps faster lysis is accomplished with two enzymes having different specificities.

There seems to be no significance in the particular specificities of the two phage-induced autolysins. The range of enzyme specificities of phage-induced autolysins is just as large as that of the bacterial enzymes. For example, $E$. coli phage $\lambda$ specifies an endopeptidase (Taylor, 1971), phage T2 an endo- $N$-acetylmuramidase (Primosigh et al., 1961) and phage T7 an $\mathrm{N}$-acetylmuramoyl-L-alanine amidase (Kleppe et al., 1977).

The molecular weight of the phage-induced amidase was rather low compared with that of the bacterial amidase $(14800$ as against 51000$)$. This may reflect the evolutionary size-limitation pressures imposed upon a phage genome, although large differences in molecular weight have been found in bacterial endo-muramidases isolated from two other strains of B. subtilis (13000 and 90000: Takahara et al., 1974; Okada \& Kitahata, 1973).

We thank Mr P. N. Sockett for his excellent technical assistance in constructing strain RB1163.

\section{REFERENCES}

Buxton, R. S. (1976). Prophage mutation causing heat-inducibility of defective Bacillus subtilis bacteriophage PBSX. Journal of Virology 20, 22-28.

Buxton, R. S. (1980). Selection of Bacillus subtilis 168 mutants with deletions of the PBSX prophage. Journal of General Virology 46, 427-437.

Campbell, A. \& Del Campillo-Campbell, A. (1963). Mutant of lambda bacteriophage producing a thermolabile endolysin. Journal of Bacteriology 85, 1202-1207.

Fan, D. P. \& Beckman, M. M. (1973). Micrococcus lysodeikticus bacterial walls as a substrate specific for the autolytic glycosidase of Bacillus subtilis. Journal of Bacteriology 114, 804-813.

FeIN, J. \& Rogers, H. J. (1976). Autolytic-enzyme deficient mutants of Bacillus subtilis 168. Journal of Bacteriology 127, 1427-1442.

ForsberG, C. W. \& WARD, J. B. (1972). N-Acetylmuramyl-L-alanine amidase of Bacillus licheniformis and its L-form. Journal of Bacteriology 110 , 878-888.

Ghuysen, J.-M., Tipper, D. J. \& Strominger, J. L. (1966). Enzymes that degrade bacterial cell walls. Methods in Enzymology 8, 685-699.

Herbold, D. R. \& GlaSER, L. (1975). Bacillus subtilis $\mathrm{N}$-acetylmuramic acid L-alanine amidase. Journal of Biological Chemistry 250, 1676-1682.

Kleppe, G., Jensen, H. B. \& Pryne, I. F. (1977). Purification and characterisation of the lytic enzyme $\mathrm{N}$-acetylmuramyl-L-alanine amidase of bacteriophage T7. European Journal of Biochemistry 76, 317-326.
Okada, S. \& Kitahata, S. (1973). Purification and properties of bacterial lysozyme. Journal of Fermentation Technology 51, 705-712.

Primosigh, J., Pelzer, H., MaAss, D. \& Weidel, W. (1961). Chemical characterisation of mucopeptides released from the Escherichia coli B cell wall by enzymic action. Biochimica et biophysica acta $\mathbf{4 6}$, 68-80.

Rogers, H. J. (1979). The function of bacterial autolysins. In Microbial Polysaccharides and Polysaccharases, pp. 237-268. Edited by R. C. W. Berkeley, G. W. Gooday \& D. C. Ellwood. London: Academic Press.

Shibaev, V. N., Duckworth, M., Archibald, A. R. \& BADDILEY, J. (1973). The structure of a polymer containing galactosamine from walls of Bacillus subtilis 168. Biochemical Journal 135, 383-384.

Sussman, R. \& JACOB, F. (1962). Sur un système de répression thermosensible chez le bactériophage $\lambda$ d'Escherichia coli. Comptes rendus hebdomadaires des séances de l'Académie des sciences 254, 15171519.

Takahara, Y., Machigaki, E. \& Maruo, S. (1974). General properties of endo- $N$-acetylmuramidase of Bacillus subtilis YT-25. Agricultural and Biological Chemistry 38, 2357-2365.

TAYLOR, A. (1971). Endopeptidase activity of phage $\lambda$-endolysin. Nature New Biology 234, 144-145.

TAYLOR, C., Rogers, H. J. \& WARd, J. B. (1980). The autolytic endo- $\beta$ - $N$-acetylglucosaminidase of Bacillus subtilis: purification and properties. Society for General Microbiology Quarterly 7, 73-74. 
Thompson, J. S. \& Shockman, G. D. (1968). A modification of the Park and Johnson reducing sugar determination suitable for the assay of insoluble materials; its application to bacterial cell walls. Analytical Biochemistry 22, 260-268.

TyNeCKA, Z. \& WARD, J. B. (1975). Peptidoglycan synthesis in Bacillus licheniformis. The inhibition of cross-linking by benzylpenicillin and cephaloridine in vivo accompanied by the formation of soluble peptidoglycan. Biochemical Journal 146, 253-267.

WARD, J. B. (1974). The synthesis of peptidoglycan in an autolysin-deficient mutant of Bacillus licheniformis N.C.T.C. 6346 and the effect of $\beta$-lactam antibiotics, bacitracin and vancomycin. Biochemical Journal 141, 227-241.
Williamson, R. \& Ward, J. B. (1979). Characterization of the autolytic enzymes of Clostridium perfringens. Journal of General Microbiology 114, 349-354.

Williamson, R. \& WARD, J. B. (1981). Deficiency of autolytic activity in Bacillus subtilis and Streptococcus pneumoniae is associated with a decreased permeability of the wall. Journal of General Microbiology 125, 325-334.

WYKE, A. W. \& WARD, J. B. (1977). Biosynthesis of wall polymers in Bacillus subtilis. Journal of Bacteriology 130, 1055-1063. 